\title{
REPUTASI AUDITOR SEBAGAI PEMODERASI PENGARUH FINANCIAL DISTRESS DAN AUDIT FEE PADA AUDITOR SWITCHING
}

\author{
Erike Wulandari ${ }^{1}$, Dwi Cahyono ${ }^{2}$, Nina Martiana ${ }^{3}$ \\ ${ }^{1,2,3}$ Program Studi Akuntansi Fakultas Ekonomi dan Bisnis \\ Universitas Muhammadiyah Jember \\ e-mail: wulandari123@gmail.com
}

\begin{abstract}
Abstrak
Penelitian ini menggunakan auditor switching dimana auditor switching adalah perubahan auditor atau perubahan dari Kantor Akuntan Publik yang dilakukan oleh perusahaan. Tujuan penelitian adalah untuk mengetahui pengaruh financial distress dan biaya audit terhadap pergantian auditor dengan reputasi auditor sebagai variabel moderasi. Populasi dalam penelitian dilakukan di perusahaan manufaktur yang terdaftar di Bursa Efek Indonesia (BEI) pada 2016-2018, di mana 163 perusahaan terdaftar di bursa efek dan sampel akhir adalah 37 perusahaan. Teknik pengumpulan data menggunakan analisis statistik deskriptif, analisis regresi logistik (MRA). Hasilnya menunjukkan bahwa kesulitan keuangan dan biaya audit tidak berpengaruh pada pergantian auditor. Reputasi auditor tidak dapat memoderasi pengaruh kesulitan keuangan dan biaya audit pada pergantian auditor.
\end{abstract}

Kata kunci : Financial distress, fee audit, switching auditor, reputasi auditor

\begin{abstract}
This research used auditor switching where auditor switching is an auditor change or change of Public Accounting firm that conducted by the company. The purpose of research is to know the effect of financial distress and audit fee on auditor switching with the auditor reputation as moderation variable. The population in research was conducted in manufactoring comapany which is listed on the Indonesia stock exchange (IDX) in 2016-2018, where 163 companies are listed on the stock exchange and the final sample is 37 companies. The data collection technique used descriptive statistical analysis, logistic regression analysis (MRA). The result shows that financial distress and audit fees have no effect on auditor switching. The auditor's reputation can not moderate the effect of financial distress and audit fees on auditor switching.
\end{abstract}

Keywords : Financial distress, audit fee, auditor switching, reputasi auditor 


\section{PENDAHULUAN}

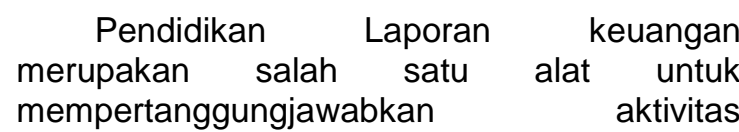
manajemen. Laporan keuangan digunakan sebagai dasar dalam menilai posisi dan kegiatan operasional perusahaan serta dapat digunakan untuk menilai kinerja manajemen dalam suatu perusahaan. Untuk mengurangi potensi kecurangan dalam laporan keuangan yang disebabkan oleh kepentingan manajemen, maka perusahaan memerlukan peran auditor independen untuk memastikan bahwa laporan keuangan perusahaan relevan dan reliabel.

Untuk dapat meningkatkan kepercayaan pihak yang berkaitan dengan perusahaan, maka seorang auditor independen harus mampu menjamin bahwa laporan keuangan relevan dan reliabel (Muliana dan Icuk, 2010). Independensi auditor merupakan kunci utama dalam menilai kewajaran laporan keuangan, karena apabila seorang auditor yang mampu mempertahankan independensinya maka kemungkinan kualitas audit menjadi lebih tinggi dan auditor juga tidak mudah terpengaruh oleh kepentingan kliennya. Fenomena pergantian auditor atau pergantian Kantor Akuntan Publik (Auditor switching) sering terjadi di Indonesia khususnya di Bursa Efek Indonesia. Pergantian auditor ini merupakan bentuk dari suatu konflik yang terjadi antara klien dan auditornya.

Putri Sima (2018) menyatakan bahwa hubungan kerja yang panjang antara auditor dengan klien bisa menyebabkan auditor memiliki kecenderungan kehilangan independensinya dan menjadi dasar dalam melakukan pergantian auditor. Laporan keuangan yang tidak independen menyebabkan terjadinya kegagalan dalam penyajian laporan keuangan. Pengaruh independensi terhadap kualitas laporan keuangan terbukti dengan adanya beberapa skandal yang pernah terjadi, fenomena kasus Enron dengan KAP Arthur Anderson yang mana Enron merupakan perusahaan besar yang bergerak dalam industri energi telah melakukan kecurangan dengan memanipulasi data laporan keuangan perusahaan, dimana Enron mencatat keuntungan 600 juta \$AS padahal saat itu perusahaan mengalami kerugian yang besar melibatkan KAP besar yang masuk dalam jajaran lima KAP terbesar di dunia atau Big Five. Disamping itu banyak pula pihak yang berpendapat bahwa hal ini dikarenakan akibat adanya hubungan kerja sama yang panjang antar KAP dan kliennya yang memungkinkan terjadi resiko keakraban yang berlebihan (expensive familiarity), sehingga hal ini pun juga bisa mempengaruhi objektivitas dan independesnsi seorang KAP. Fakta ini menjadikan alasan bagi perusahaan untuk melakukan auditor switching.

Untuk menjaga independensi auditor, Pemerintah Indonesia telah mengatur kewajiban rotasi auditor dengan mengeluarkan surat Keputusan Menteri Keuangan Republik Indonesia Nomor 17/PMK.01/2008 tentang "Jasa Akuntan Publik", yang mengatur bahwa pemberian jasa audit umum atau laporan keuangan dari suatu entitas dapat dilakukan paling lama untuk 6 (enam) tahun buku berturut-turut oleh KAP dan 3 (tiga) tahun buku berturut-turut oleh seorang akuntan publik kepada satu klien yang sama (pasal 3 ayat 1 ). Kemudian, KAP dan Akuntan Publik boleh menerima kembali penugasan setelah satu tahun buku tidak memberikan jasa audit umum atas laporan keuangan kepada klien tersebut (pasal 3 ayat 2 dan 3). Fakta mengenai alasan pergantian auditor tidak pernah diungkapkan pada laporan keuangan. Nazri et al. (2012) menyatakan bahwa perusahaan selalu menyembunyikan alasan yang sesungguhnya dibalik proses pergantian auditor. Selain itu, fee audit dapat dipengaruhi oleh financial distress. Schwartz dan Soo (1995) menyatakan bahwa perusahaan yang mengalami kesulitan keuangan (financial distress) dalam perusahaannya akan cenderung terancam bangkrut dan melakukan perpindahan KAP. Financial distress adalah keadaan perusahaan yang menunjukkan kondisi perusahaan yang mengalami kesulitan keuangan dan memungkinkan terjadinya kebangkrutan. Perusahaan yang mengalami kepailitan dalam keuangan lebih cenderung mendapat respon jelek (negatif) dari para investor sehingga investor tidak memiliki kepercayaan lagi terhadap kinerja perusahaan.

Penelitian-penelitian yang dilakukan oleh Putri Sima (2018), Widyanti (2016), Sinarwati (2010), Setyorini dan Aloysia (2006) serta Yasmin (2013) mengungkapkan bahwa financial distress berpengaruh positif pada auditor switvhing. Berbeda dengan penelitian yang dilakukan oleh, Damayanti dan Sudarma (2007), Kurniasari (2014), serta Yuka dan M. Rizal (2016) menyatakan bahwa Financial distress tidak berpengaruh pada auditor switching.

Lebih lanjut, penelitian ini menggunakan reputasi auditor sebagai variabel pemoderasi. Reputasi auditor merupakan nama besar yang dimiliki seorang auditor atas kerja, prestasi, dan kepercayaan publik yang disandang 
auditor. Perusahaan akan mencari KAP yang kredibilitasnnya tinggi sehingga dapat meningkatkan kredibilitas laporan keuangan perusahaan (Halim,1997). Penelitian yang dilakukan Mahantara (2013), dan Yasmin (2013), dan mengungkapkan hasil bahwa reputasi auditor mempengaruhi auditor switching. Berbeda dengan penelitian yang dilakukan Sinarwati (2010) yang mengatakan bahwa reputasi auditor tidak berpengaruh paada auditor switching. Berdasarkan latar belakang diatas, maka peneliti melakukan penelitian dengan judul "Reputasi Auditor Sebagai Pemoderasi Pengaruh Financial Distress Dan Audit Fee Pada Auditor Switching (Studi Empiris pada Perusahaan Manufaktur yang Terdaftar di Bursa Efek Indonesia Tahun 2016-2018)". Tujuan penelitian ini untuk mengetahui pengaruh masing-masing variabel. Adapun manfaat penelitian ini adalah sebagai bahan informasi pertimbangan bagi pihak manajemen perusahaan sehubungan dengan pelaksanaan auditor switching dan implikasinya bagi perusahaan, bisa menjadi sumber referensi dan informasi untuk penelitian yang akan datang dalam mengembangkan ilmu pengetahuan untuk perkembangan dan kemajuan dunia pendidikan khususnya auditor switching.

\section{METODE}

Penelitian ini menggunakan penelitian kuantitatif dengan pendekatan asosiasif. Variabel yang digunakan dalam penelitian ini adalah finacial distress dan audit fee sebgai variabel indpenden, auditor switching sebagai variabel dependen dan reputasi auditor sebgai variabel moderasi. Populasi yang digunakan dalam penelitian ini adalah perusahaan manufaktur yang terdaftar di Bursa Efek Indonesia tahun 2016-2018. Teknik pengambilan sampel yang digunakan yaitu metode purposive sampling dengan kriteria: 1) Perusahaan manufaktur yang terdaftar di Bursa Efek Indoenesia periode 2016-2018; 2) Perusahaan manufaktur yang terdaftar secara berturut-turut di Bursa Efek Indonesia selama periode tahun 2016-2018; 3) Perusahaan tersebut memiliki laporan keuangan tahunan dan laporan audit selama periode tahun 2016-
2018; 4) Perusahaan tersebut melakukan pergantian Kantor Akuntan Publik selama periode tahun 2016-2018. Dari kriteria tersebut diperoleh data untuk sampel sebanyak 37 perusahaan dengan selang periode penelitian selama tiga tahun. Teknik analisis data yang digunakan ialah analisis statistik deskriptif, analisis regresi logistik, dan Moderated Regression Analysis (MRA). Penelitian menggunakan analisis regresi logoikik karena variabel terikat dalam penelitian ini menggunakan variabel dummy. Analisis regresi logistik dipakai untuk menguji apakah probabilitas terjadinya variabel terikat dapat diprediksi dengan variabel bebasnya. Teknik analisis regresi logistik tidak memerlukan asumsi normalitas data pada variabel bebasnya (Ghozali, 2011) dan mengabaikan heteroskedastisitas (Gujarati, 2003). Pengujian ini menggunakan variabel moderasi didalamnya. Variabel moderasi ini nantinya dapat membuktikan apa mungkin akan memperkuat atau memperlemah hubungan variabel bebas dan variabel terikatnya.

\section{HASIL DAN PEMBAHASAN}

Perusahaan manufaktur yang terdaftar di Bursa Efek Indonesia (BEI) selama periode 2016-2018 terdapat sebanyak 163 perusahaan, pengambilan sampel dalam penelitian ini dilakukan dengan menggunakan metode puposive sampling dimana yang memenuhi kriteria dalam penentuan sampel sebanyak 33 perusahaan sehingga total pengamatan yang dijadikan sampel penelitian adalah sebanyak 99 perusahaan. Statistik deskriptif memberikan deskripsi perihal karakteristik data yang didalamnya memuat angka raa-rata (mean), maksimum minimum, dan deviasi standar (standart deviation). Mean digunakan sebagai spekulasi rata-rata sampel yang akan diambil dari populasi. Maksimum dan minimum digunakan untuk melihat nilai maksimum dan minimum dari populasi yang akan diteliti. Standar deviasi digunakan sebagai acuan untuk menilai disperse rata-rata dari sampel.

Hasil pengujian statistik deskriptif disajikan dalam Tabel 1 sebagai berikut : 
Tabel 1. Hasil Statistik Deskriptif

\begin{tabular}{|c|c|c|c|c|c|}
\hline & $\mathrm{N}$ & Minimum & Maximum & Mean & $\begin{array}{c}\text { Std. } \\
\text { Deviation }\end{array}$ \\
\hline Financial Distress & 99 & $-10,19$ & 162,19 & 3,0741 & 16,36150 \\
\hline Audit Fee & 99 & 18,42 & 22,32 & 19,6430 & ,90700 \\
\hline Auditor Switching & 99 & 0 & 1 & ,39 & ,491 \\
\hline Reputasi Auditor & 99 & 0 & 1 &, 17 & ,379 \\
\hline $\begin{array}{l}\text { Financial Distress * } \\
\text { Reputasi Auditor }\end{array}$ & 99 & $-5,02$ & 2,04 & ,1226 & ,70474 \\
\hline $\begin{array}{l}\text { Audit Fee * Reputasi } \\
\text { Auditor }\end{array}$ & 99 & ,00 & 22,32 & 3,5620 & 7,86887 \\
\hline Valid N (listwise) & 99 & & & & \\
\hline
\end{tabular}

Berdasarkan hasil statistik desktiptif diperoleh sebanyak 99 data observasi yang berasal dari perkalian antara periode penelitian (3 tahun dari 2016-2018) dengan jumlah perusahaan sampel 33 perusahaan. Tabel 4.1 menunjukkan statsitik deskriptif masingmasing variabel penelitian. Pada tabel diatas, nilai minimum variabel Financial distress (X1) sebesar $-10,19$, nilai maksimum sebesar 162,19. Nilai minimum sebanding dengan tabulasi data perusahaan Eterindo Wahanatama Tbk tahun 2018 dan nilai maksimum sebanding dengan tabulasi data perusahaan Eterindo Wahanatama Tbk tahun 2017. Nilai rata-rata (mean) sebesar 3,0741 dan standar deviasi sebesar 16,36150. Nilai rata-rata (mean) sebesar 16,36150 membuktikan bahwa terdapat lebih banyak perusahaan yang mengalami financial distress daripada perusahaan yang sehat atau tidak mengalami financial distress.

Variabel Audit fee (X2) memiliki nilai minimum sebesar 18,42 dan nilai maksimum sebesar 22,32. Nilai minimum sebanding dengan tabulasi data perusahaan Sunson Textile Manufacture Tbk tahun 2016 \& 2017 dan nilai maksimum sebanding dengan tabulasi data perusahaan Japfa Comfeed Indonesia Tbk tahun 2018. Nilai rata-rata (mean) sebesar 19,6430 dan standar deviasi sebesar 0,90700. Nilai mean sebesar 19,6430 membuktikan bahwa audit fee yang dibayarkan oleh perusahaan tinggi.

Variabel Auditor Switching $(\mathrm{Y})$ memiliki nilai minimum sebesar 0 dan nilai maksimum sebesar 1 . Nilai minimum sebanding dengan tabulasi data dimana perusahaan yang mengalami auditor switching 0 sebanyak 57 perusahaan dan perusahaan yang memiliki nilai maksimum 1 sebanyak 39 perusahaan. Nilai rata-rata (mean) sebesar 0,39 dan standar deviasi sebesar 0,491. Nilai mean sebesar 0,39 membuktikan bahwa perusahaan yang melakukan auditor switching lebih sedikit dibandingkan perusahaan yang tidak melakukan auditor switching.

Variabel Reputasi auditor (Z) memiliki nilai minimum sebesar 0 dan nilai maksimum sebesar 1 . Nilai minimum sebanding dengan tabulasi data dimana perusahaan yang memiliki reputasi auditor 0 sebanyak 82 perusahaan dan perusahaan yang memiliki nilai maksimum 1 sebanyak 17 perusahaan. Nilai rata-rata (mean) sebesar 0,17 dan standar deviasi sebesar 0,379 . Nilai rata-rata (mean) sebesar 0,17 membuktikan bahwa perusahaan yang menggunakan KAP yang berafiliasi dengan Big 4 lebih sedikit dibandingkan dengan perusahaan yang menggunakan KAP non Big 4.

Menguji Kelayakan Model Regresi (Hosmer and Lemeshow's)

Pengujian ini dilihat dengan menggunakan nilai Chi-Square dengan nilai signifikansi sebesar 0,05. Jika hasilnya menunjukkan kurang dari atau sama dengan 0,05 , maka hipotesis 0 (nol) ditolak karena terdapat perbedaan signifikan antara model dan nilai observasi. Sebaliknya jika nilai lebih dari 0,05 , maka hipotesis nol tidak dapat ditolak yang mana model tersebut dapat menjelaskan nilai risetnya dan dapat dikatakan model ini diterima karena cocok dengan data observasinya.

Berikut ini disajikan Tabel 2 uji Hosmer and Lemeshow's sebagi berikut :

Tabel 2. Hasil Uji Hosmer and Lemeshow's

\begin{tabular}{lrrrrr}
\hline Step & Chi-square & df & \multicolumn{2}{c}{ Sig. } \\
\hline 1 & 9,976 & & 8 & &, 267 \\
\hline
\end{tabular}


Kelayakan model regresi digunakan pengujian Chi-Square dengan nilai signifikansi sebesar 0,05. Dari tabel uji hosmer and lemeshow's diatas dapat dilihat bahwa nilai chi-square sebesar 9,976 dengan nilai signifikansinya sebesar 0,267 . Hasil tersebut menyatakan nilai signifikansi uji Hosmer and Lemeshow yaitu sebesar 0,267 yang lebih besar dari $0,05(0,267>0,05)$ maka hipotesis nol diterima dan dapat dikatakan model penelitian ini mampu memprediksi nilai observasinya atau dapat dikatakan model dapat diterima atau fit karena cocok dengan data observasinya (Ghozali,2011).

Menilai Keseluruhan Model (Overall Model Fit) Pengujian ini dilakukan dengan membandingkan nilai antara -2 Log Likelihood $(-2 L L)$ pada awal (Block Number $=0$ ) dengan nilai -2 Log Likelihood (-2LL) pada akhir (Block Number $=1$ ). Apabila terdapat penurunan nilai likelihood (-2LL) membuktikan bahwa model regresi yang baik atau dengan kata lain model yang dihipotesiskan fit dengan data. Hasil pengujian disajikan dalam Tabel uji Overall Model Fit sebagai berikut :

Tabel 3. Perbandingan nilai -2LL Awal dengan -2LL Akhir

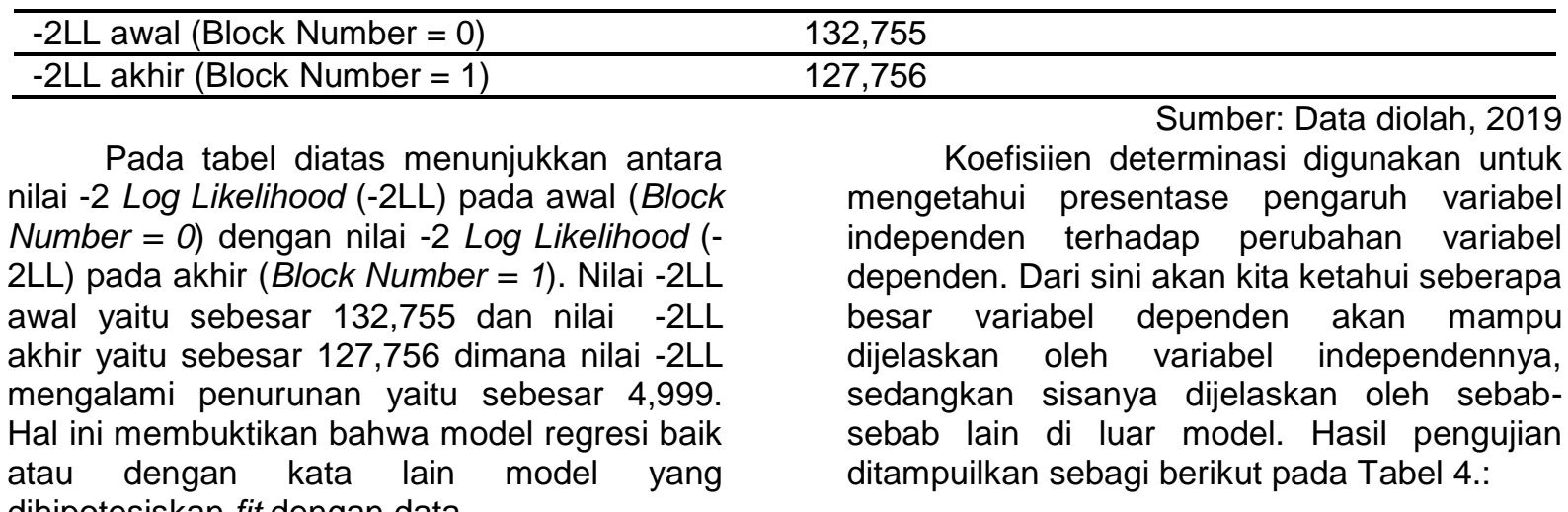
dihipotesiskan fit dengan data.

Hasil Uji Koefisien Determinasi (Nagelkerke $R$ Square)

Tabel 4. Uji Koefisien Determinasi (Nagelkerke R Square)

\begin{tabular}{|c|c|}
\hline -2 Log likelihood & $\begin{array}{c}\text { Cox \& Snell R } \\
\text { Square }\end{array}$ \\
\hline $127,756^{\mathrm{a}}$ & ,049 \\
\hline $\begin{array}{l}\text { Tabel diatas menyatakan bahwa nilai } \\
\text { gelkerke's } R \text { Square sebesar } 0,067 \text { atau } \\
\text { ma dengan } 6,7 \% \text {. Hal ini berarti variabel } \\
\text { bas yang digunakan dalam penelitian ini } \\
\text { itu financial distress dan audit fee } \\
\text { empengaruhi variabel terikat auditor } \\
\text { itching sebesar } 6,7 \% \text { sedangkan sisanya }\end{array}$ & $\begin{array}{l}\text { Sumber: Data diolah, } 201 \\
\text { menunjukkan kekuatan prediksi dari mod } \\
\text { regresi untuk memprediks kemungkina } \\
\text { terjadinya variabel terikat yang dinyataka } \\
\text { dalam persentase. Matrik klasifikasi digunaka } \\
\text { untuk memprediksi kemungkinan terjadiny } \\
\text { perpindahan KAP yang dilakukan ole } \\
\text { perusahaan. Hasil pengujian disajikan dala } \\
\text { tabel uji Overall Model Fit sebagai berikut: }\end{array}$ \\
\hline
\end{tabular}

Tabel 5. Hasil Matrik Klasifikasi

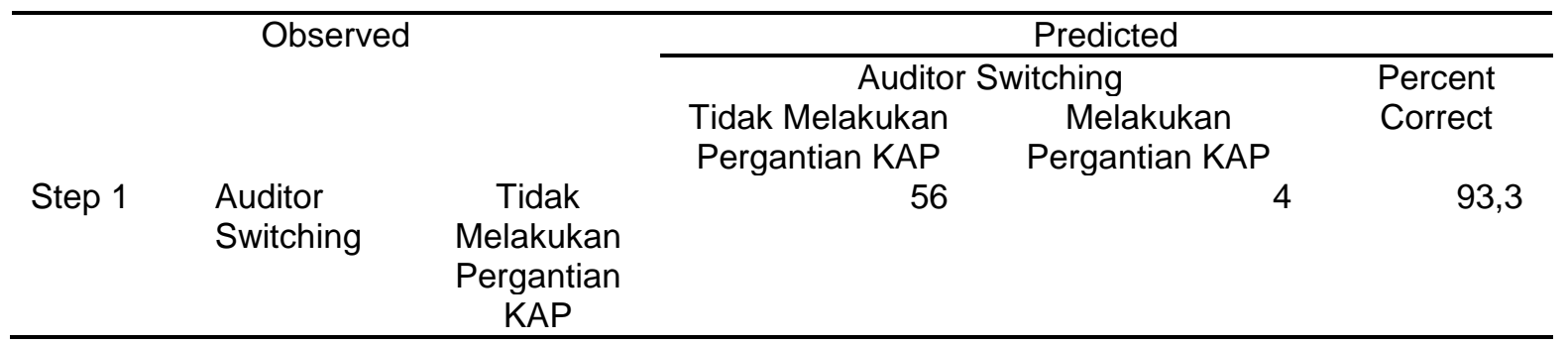




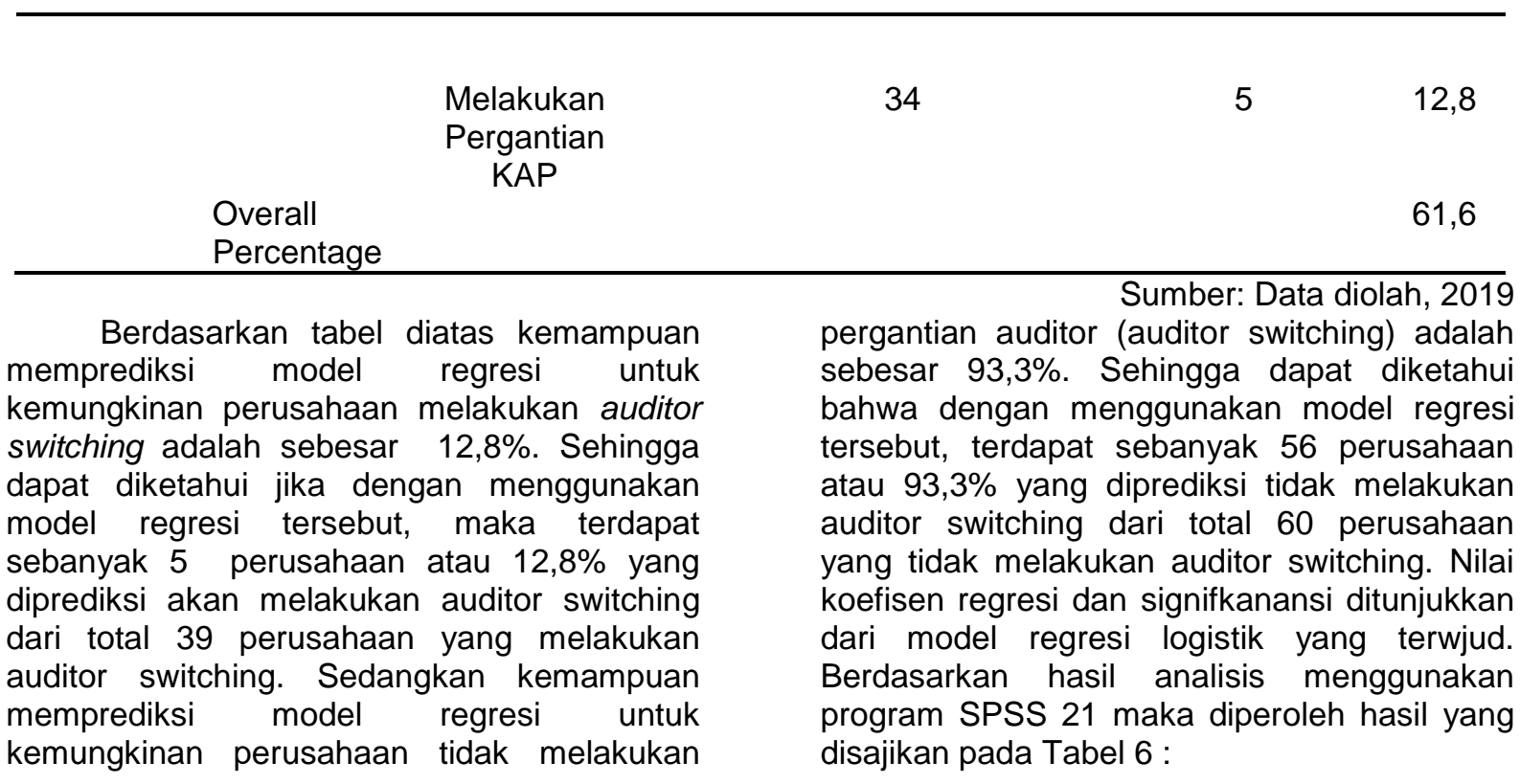

Tabel 6. Hasil Analisis Regresi Logistik

\begin{tabular}{|c|c|c|c|c|c|c|c|}
\hline & & B & S.E. & Wald & df & Sig. & $\operatorname{Exp}(B)$ \\
\hline \multirow[t]{2}{*}{ Step 1} & FD & ,024 & ,028 & ,739 & 1 & ,390 & 1,024 \\
\hline & $\begin{array}{l}\text { LNFEE } \\
\text { RA } \\
\text { FD_RA } \\
\text { LNFEE_RA } \\
\text { Constan }\end{array}$ & $\begin{array}{r}, 364 \\
-3,423 \\
, 406 \\
, 146 \\
-7,641\end{array}$ & $\begin{array}{r}, 307 \\
15,631 \\
, 531 \\
, 758 \\
5,990\end{array}$ & $\begin{array}{r}1,402 \\
, 048 \\
, 584 \\
, 037 \\
1,627\end{array}$ & $\begin{array}{l}1 \\
1 \\
1 \\
1 \\
1\end{array}$ & $\begin{array}{l}, 236 \\
, 827 \\
, 445 \\
, 847 \\
, 202\end{array}$ & $\begin{array}{r}1,439 \\
, 033 \\
1,501 \\
1,158 \\
, 000\end{array}$ \\
\hline
\end{tabular}

Hasil pengujian terhadap koefisien regresi menghasilkan model berikut ini:

$$
\begin{aligned}
& \text { Ln } \frac{\text { SWITCH }}{1 \text {-SWITCH }}=-7,641+0,024 \mathrm{FD}+ \\
& \begin{array}{l}
0,364 \text { LNFEE }-3,423 R A+ \\
0,406 \text { FD*RA }
\end{array} \\
& 0,146 \text { LNFEE }{ }^{*} \text { RA }+ \text { Ketik } \\
& \text { persamaan di sini. }
\end{aligned}
$$

Berdasarkan hasil persamaan diatas dapat diinterprestasikan hasil sebagai berikut:

Variabel FD (Financial Distress) Koefisien regresi variabel financial distress sebesar 0,024 yang berarti setiap peningkatan financial distress, dengan asumsi variabel lainnya konstan, maka kecenderungan auditor switching yang dilakukan perusahaan meningkat. Berdasarkan nilai koefisien regresi yang bernilai positif sebesar 0,024 serta nilai signifikansi diperoleh nilai 0,390 yaitu lebih besar dari 0,05 sehingga financial distress tidak berpengaruh pada auditor switching.

Variabel LNFEE (Audit Fee) Koefisien regresi variabel audit fee sebesar 0,364 yang berarti setiap peningkatan audit fee dengan asumsi variabel bebas lainnya dianggap konstan, maka kecenderungan auditor switching yang dilakukan perusahaan meingkat. Berdarkan nilai koefisien regresi yang bernilai positif sebesar 0,364 dengan nilai signifikansi sebesar $0,236>0,05$, sehingga audit fee tidak berpengaruh pada auditor switching.

Variabel RA (Reputasi Auditor) Koefisien regresi variabel reputasi auditor bernilai negatif sebesar $-3,423$ yang berarti apabila reputasi auditor naik, dengan asumsi variabel bebas lainnya dianggap konstan, maka kecenderungan auditor switching yang dilakukan perusahaan meningkat. Variabel
FD RA
(Financial

Distress* Reputasi Auditor) Koefisien regresi interaksi antara financial distress dan reputasi auditor dimana menunjukkan nilai koefisien bernilai positif dengan nilai sebesar 0,406 dengan nilai signifikansi sebesar 0,445 > 0,05 . Hasil menunjukkan bahwa reputasi auditor tidak dapat memoderasi pengaruh financial distress pada auditor switching.

$$
\text { Variabel LNFEE_RA (Audit }
$$

fee*Reputasi Auditor) Koefisien regresi interaksi antara audit fee dan reputasi auditor menunjukkan nilai koefisien bernilai positif dengan nilai sebesar 0,146 dengan nilai 
signifikansi 0,847 >0,05. Hasil tersebut menunjukkan bahwa reputasi auditor tidak dapat memoderasi pengaruh audit fee pada auditor switching.

Pengujian Hipotesis

Pengujian hipotesis ini dilakukan untuk melihat hubungan atau pengaruh yang terjadi antara variabel. Terbukti atau tidaknya hasil pengujian dinyatakan pada tabel. Penjelasan dari tabel adalah sebagai berikut:

1. Pengujian $\mathrm{H}_{1}$ : Financial distress berpengaruh positif pada auditor switching

Hipotesis pertama menunjukkan bahwa financial distress berpengaruh positif pada auditor switching. Hasil pengujian berdasarkan tabel hasil uji regresi logistik variabel financial distress menunjukkan bahwa koefisien regresi positif sebesar 0,024 dengan tingkat signifikansi sebesar 0,390 lebih besar dari 0,05 $\left(\alpha=5 \%\right.$ ). Hal ini disimpulkan bahwa $\mathrm{H}_{0}$ diterima dan $\mathrm{H}_{1}$ ditolak, yang artinya bahwa variabel financial distress tidak berpengaruh pada auditor switching.

2. Pengujian $\mathrm{H}_{2}$ : Audit fee berpengaruh positif pada auditor switching

Hipotesis kedua menyatakan bahwa audit fee berpengaruh positif pada auditor switching. Hasil pengujian menunjukkan bahwa koefisien regresi positif sebesar 0,364 dengan tingkat signifikansi sebesar 0,236 lebih besar dari 0,05 $(\alpha=5 \%)$. Hal ini disimpulkan bahwa $\mathrm{H}_{0}$ diterima dan $\mathrm{H}_{2}$ ditolak, yang artinya bahwa variabel audit fee tidak berpengaruh pada auditor switching.

3. Pengujian $\mathrm{H}_{3}$ : Reputasi auditor memperkuat pengaruh financial distress pada auditor switching

Hipotesis ketiga menayatakan bahwa reputasi auditor memoderasi pengaruh financial distress pada auditor switching. Hasil pengujian menunjukkan bahwa koefisien regresi positif sebesar 0,406 dengan tingkat signifikansi sebesar 0,445 lebih besar dari 0,05 ( $\alpha=5 \%$ ). Hal ini dapat disimpulkanbahwa $\mathrm{H}_{0}$ diterima dan $\mathrm{H}_{3}$ ditolak, yang artinya bahwa reputasi auditor tidak dapat memoderasi pengaruh financial distress pada auditor switching.

4. Pengujian $\mathrm{H}_{4}$ : Reputasi auditor memperlemah pengaruh audit fee pada auditor switching

Hipotesis keempat menyatakan bahwa reputasi auditor memperlemah pengaruh audit fee pada auditor switching. Hasil pengujian menunjukkan bahwa koefisien regresi positif sebesar 0,146 dengan tingkat signifikansi sebesar 0,847 lebih besar dari 0,05 ( $\alpha=5 \%$ ). $\mathrm{Hal}$ ini dapat dismpulkan bahwa $\mathrm{H}_{0}$ diterima $\mathrm{H}_{4}$ ditolak, yang artinya bahwa reputasi auditor tidak dapat memoderasi pengaruh audit fee pada auditor switching.

Pembahasan Hasil Penelitian

Hasil penelitian yang dilakukan pada pengujian $\mathrm{H}_{1}-\mathrm{H}_{4}$ menyatakan bahwa terdapat hipotesis yang ditolak. Pembahasan masingmasing hipotesis dinyatakan sebagai berikut:

1. $\mathrm{H}_{1}$ : Pengaruh financial distress pada auditor switching

Hasil pengujian dengan menggunakan regresi logistik menunjukkan nilai koefisien regresi positif sebesar 0,024 dengan tingkat signifikansi sebesar 0,390 yang lebih besar dari $0,05 \quad(\alpha=5 \%) \quad(0,390>0,05)$. Hasil penelitian ini menunjukkan bahwa variabel financial distress tidak berpengaruh pada auditor switching dengan kata lain $\mathrm{H}_{1}$ ditolak. Karena selama perusahaan masih memiliki nilai cash flowyang baik, maka hal itu bisa membantu perusahaan untuk melunasi hutang-hutangnya, sehingga perusahaan tidak perlu melakukan auditor switching. Seperti halnya salah satu contoh pada sampel yang dianalisis oleh peneliti pada PT Mustika Ratu Tbk, dimana perusahaan tersebut memiliki nilai modal yang berada diatas nilai hutang sehingga dengan kata lain hal itu cukup mampu memenuhi hutang atau membayar kewajiban eksternal.

Hasil penelitian ini sesuai dengan hasil penelitian yang dilakukan Ardiati (2006), Damayanti dan Sudarma (2007), Aprilia (2013), Astuti (2014), Faradila (2016) dan Ismiyaca (2016) yang menyatakan bahwa financial distress tidak berpengaruh pada auditor switching. Menurut Aprialia (2013) menyatakan, Kesulitan keuangan tidak menjadi faktor yang mendorong suatu perusahaan untuk melakukan pergantian KAP. Perusahaan dalam konidisi financial distress cendderung tidak melakukan pergantian KAP ini disebabkan pergantian auditor pada suatu perusahaan yang terlalu sering akan meningkatkan fee audit. Disamping itu menurut Ismiyaca (2016) menyatakan pada kenyataannya belum tentu perusahaan yang mengalami kondisi keuangan memburuk akan melakukan auditor switching terlebih perusahaan sampel sebagian besar menggunakan jasa KAP Big 4, dengan demikian perpindahan ke penggunaan jasa KAP yang lain akan menjadi pertimbangan besar dan akan semakin menyulitkan kondisi keuangan perusahaan karena adanya biaya baru yang akan dikeluarkan. Menurut Ardiati (2006) menjelaskan, pada kenyataannya belum tentu perusahaan yang megalami financial distress akan melakukan pergantian 
auditor karena beberapa faktor, yaitu: pertama, di Indonesia, perusahaan-perusahaan akan mempertimbangkan secara serius tentang masalah pergantian auditor karena auditor yang selama ini mereka gunakan telah mengetahui dan mengerti kondisi perusahaan. Jika perusahaan mengganti auditor, perussahaan khawatir jika auditor yang baru akan melakukan pemeriksaan terhadap sistem pembukuan dan menilai rendah standar mutu pembukuan perusahaan mereka. Hal ini dapat mengakibatkan keterlambatan dalam penyajian laporan keuangan yang menyebabkan perusahaan menanggung biaya denda keterlambatan. Kedua, adanya benturan kepentingan kepada auditor dalam melaksanakan tugas audit dan memberikan jasa konsultan. Benturan kepentingan ini dapat mengganggu independensi auditor yang akan mempengaruhi opini audit. Perusahaan di Indonesia merasa hal tersebut dapat memberikan keuntungan, sehingga perusahaan enggan melakukan pergantian auditor. Hasil penelitian ini tidak mendukung penelitian Fitriani dan Zulaikha (2014), Dwiyanti dan Sabeni (2014), dan Widyanti (2016) yang menunjukkan bahwa financial distress berpengaruh pada auditor switching.

Manajemen perusahaan terkadang dihadapkan pada kegagalan dalam membesarkan perusahaan. Akibatnya kelangsungan hidup (going concern) perusahaan ke depan tidak jelas. Perusahaan akan menjadi tidak sehat atau dalam kondisi yang memburuk, terlebih lagi perusahaan terus-menerus mengalami krisis yang berkepanjangan. Kondisi seperti ini memicu perusahaan kearah kebangkrutan. Dimana kebangkrutan dapat diartikan sebagai kegagalan perusahaan saat menjalankan operasi perusahaan dalam menghasilkan sebuah laba. Biasanya perusahaan yang mengalami kondisi financial distress mempunyai dorongan yang sangat kuat untuk melakukan auditor switching, karena tampak kemungkinan perusahaan tidak mampu dalam membayar fee audit untuk para Kantor Akuntan Publik besar sehingga perusahaan menginginkan untuk mengganti KAP nya dengan KAP yang lebih kecil.

Oleh karena itu, perusahaan yang mengalami financial distress atau kesulitan keuangan cenderung untuk tidak melakukan auditor switching. Hal ini disebabkan bahwa ketika perusahaan mengalami financial distress maka komdisi keuangan perusahaan tersebut juga sedang memburuk sehingga tidak memungkinkan untuk membayar auditor yang baru yang dikhawatirkan biayanya lebuh besar dari auditor sebelumnya. Kemudian, perusahaan dengan keadaan financial distress kemungkinan juga akan terkena denda karena keterlambatan dalam penyajian laporan keuangan karena dengan melakukan auditor switching, maka akan memakan waktu yang lama untuk audior yang baru dalam memahami atau mempelajari bisnis dan industri kliennya, misal auditor baru harus melakukan pemeriksaan terhadap sistem pembukuan dan menilai standar mutu pembukuan perusahaan mereka. Selain itu, pihak manajemen perusahaan akan memperhatikan persepsi dari pemegang saham, jika melakukan pergantian KAP tidak dalam waktu yang telah ditentukan didalam peraturan maka pemegang saham akan mencurigai adanya hal yang tidak beres dalam perusahaan dengan kata lin bahwa penilain yang baik tentang perusahaan oleh pemegang saham harus terus terjaga dan perusahaan juga menganggap Financial distress tidak menjadi perhatian yang utama bagi manajemen untuk mengganti auditor karena selama perusahaan masih dapat menambah modalnya maka perusahaan masih dalam keadaan baik, atau bisa jadi perusahaan telah menggunakan auditor yang dinilai memadai dalam mengaudit suatu perusahaan walaupun tingkat financial distress yang amat tinggi.

\section{2. $\mathrm{H}_{2}$ : Pengaruh audit fee pada auditor switching}

Hasil pengujian dengan menggunakan regresi logistik menunjukkan nilai koefisien regresi positif sebesar 0,364 dengan tingkat signifikansinya sebesar 0,236 yang lebih besar dari $0,05 \quad(\alpha=5 \%) \quad(0,236>0,05)$. Hal ini menunjukkan bahwa variabel audit fee tidak berpengaruh pada auditor switching dengan kata lain $\mathrm{H}_{2}$ ditolak. Hasil penelitian ini mendukung penelitian Dwiyanti dan Sabeni (2014), Handini (2017) dan Ismaya (2017) yang menyatakan bahwa variabel audit fee tidak berpengruh pada auditor switching. Penelitian yang dilakukan Lestari (2012) menyatakan bahwa audit fee yang tinggi maupun rendah tidak mempengaruhi perusahaan untuk melakukan auditor switching. Fee audit dapat didefinisikan sebagai jumlah biaya yang dibebankan oleh auditor untuk proses audit kepada perusahaan. Fee audit biasanya ditentukan sebelum memulai proses audit. Besarnya fee yang diberikan tidak berpengaruh terhadap pergantian auditor, asalkan sejalan dan memenuhi kualifikasi yang dibutuhkan perusahaan. Pergantian auditor tersebut terjadi karena perusahaan menilai kualitas 
yang dimiliki auditor tidak sesuai dengan opini yang diharapkan perusahaan. Namun disamping itu terdapat beberapa penelitian yang bertentangan dengan hasil penelitian diatas yaitu Damayanti dan Sudarma (2007), Astuti (2014), dan Wulan Indah Sari (2016) yang menyatakan bahwa audit fee berpengaruh positif pada auditor switching.

Hasil penelitian ini menunjukkan bahwa variabel audit fee tidak berpengaruh pada auditor switching dengan kata lain $\mathrm{H}_{2}$ ditolak. Tingginya fee audit yang ditetapkan oleh auditor selama ini tidak menyebabkan perusahaan untuk melakukan auditor switching kepada auditor yang menetapkan fee audit yang lebih rendah, karena perusahaan akan tetap memilih auditor yang memiliki profesionalitas tinggi dan kualitas audit yang baik, selain itu perusahaan memberikan fee audit sesuai dengan persetujuan fee audit antara pihak perusahaan dengan pihak auditor dan fee audit yang ditetapkan telah sesuai dengan profesi akuntan publik dalam jumlah yang pantas dan dapat memberikan jas audit sesuai dengan yang diatus dalam Standar Profesi Akuntan Publik (SPAP) yang berlaku.

Manajemen sebagai agent mempunyai fungsi decision making dan otoritas, dalam hal ini apabila manajemen menganggap Kantor Akuntan Publik yang dipilih sudah sesuai dalam memenuhi kriteria yang dibutuhkan dan dapat sejalan dengan pandangan manajemen yang diinginkan perusahaan tersebut, dimana penawaran audit fee yang relatif tinggi bukan merupakan suatu masalah sehingga perusahaan tidak perlu melakukan auditor switching. Jika dikaitkan dengan teori agensi yang mengasumsikan bahwa salah satu sifat agent adalah rasional, dimana dalam hal ini rasional yaitu membandingkan antara cost dan benefit, maka kondisi dimana manajemen memilih auditor dengan penawaran audit fee yang relatif tinggi akan tetapi auditor tersebut dapat sejalan dan dapat memenuhi kriteria yang dibutuhkan. Dalam hal ini dapat diartikan bahwa memberikan benefit yang lebih tinggi dari cost yang dikeluarkan, telah menggambarkan kebenaran asumsi tersebut (Dwiyanti dan Subeni, 2014).

3. $\mathrm{H}_{3}$ : Reputasi auditor memoderasi pengaruh financial distress pada auditor switching

Hasil pengujian dengan menggunakan regresi logistik menunjukkan nilai koefisien regresi positif sebesar 0,406 dengan tingkat signifikansi sebesar 0,445 yang lebih besar dari $0,05(\alpha=5 \%)(0,445>0,05)$. Hal ini menunjukkan bahwa variabel reputasi auditor tidak mampu memoderasi pengaruh financial distress pada auditor switching. Hasil penelitian ini menyatakan bahwa reputasi auditor tidak menyebabkan perusahaan untuk melakukan auditor switching. Hasil penelitian ini mendukung penelitian Rahayu (2012) dan Puspayanti (2018) yang menyatakan bahwa variabel reputasi auditor tidak mampu memoderasi hubungan antara financial distress pada auditor switching. Rahayu (2012) menyatakan bahwa apapun reputasi auditornya baik KAP besar atau KAP kecil akan berpendapat sama terhadap keadaan perusahaan yang sedang mengalami kondisi kesulitan keuangan.

Hasil pengujian hipotesis menunjukkan bahwa hipotesis ketiga $\left(\mathrm{H}_{3}\right)$ ditolak, karena reputasi auditor tidak berhasil memperkuat ataupun memperlemah hubungan antara financial distress dengan auditor switching. Hal ini menunjukkan bahwa baik auditor yang berafiliasi dengan KAP The Big 4 maupun yang non The Big 4 akan tetap memperhatikan kondisi financial distress yang sedang dihadapi oleh perusahaan, terutama dalam hal ini adalah perbandingan antara total hutang atau liabilitas dengan total ekuitas yang dimiliki oleh perusahaan. Lagipula, baik auditor yang berafiliasi dengan KAP Big 4 atau tidak berafiliasi dengan KAP Big 4 dalam memberikan pendapat tidak hanya berfokus pada kondisi financial distress berdasarkan rasio total hutang dan total ekuitas, tetapi juga melihat sisi keuangan yang masih dalam keadaaan baik, misalnya cash flow yang dimiliki perusahaan masih dalam angka positif, maka auditor beranggapan walaupun perusahaan tengah mengalami financial distress, perusahaan tersebut masih dapat melanjutkan usahanya, sehingga ketika auditor akan memberi opini selain tidak wajar juga tetap memperhatikan banyak dari segi faktor dalam keuangan. Dengan demikian, manajemen akan beranggapan bahwa apapun reputasi auditor yang dipilih perusahaan, akan tetap memberikan pendapat yang sama terkait dengan keadaan keuangan perusahaan sehingga tidak harus melakukan auditor switching. Jikalaupun terjadi auditor switching hal itu disebabkan karena peraturan mengenai rotasi auditor Peraturan Nomor 17/PMK.01/2008 tentang "Jasa Akuntan Publik".

4. $\mathrm{H}_{4}$ : Reputasi auditor memoderasi pengaruh audit fee pada auditor switching

Hasil pengujian dengan menggunakan regresi logistik menunjukkan nilai koefisien regresi positif sebesar 0,146 dengan tingkat signifikansi 0,847 yang lebih besar dari 0,05 $(\alpha=5 \%)(0,847>0,05)$. Hal ini menunjukkan 
bahwa variabel reputasi auditor tidak mampu memoderasi pengaruh audit fee pada auditor switching. Dalam teori kontigensi, sifat dasar seorang manajemen adalah situsional. Situsional yang dimaksud yaitu menghadapi konsekuensi dalam pemilihan teknik-teknik manajemen bergantung pada situasi lingkungan. Manajemen harus mengadopsi pendekatan dan strategi sesuai dengan permintaan setiap situasi yang dihadapi. Strategi manajemen untuk meningkatkan citra perusahaan dimata stakeholder yaitu salah satunya dengan menggunakan KAP yang berafiliasi dengan Big 4 (Wulandari: 2018).

Hasil penelitian ini mendukung penelitian Amalia (2015) Putri Sima (2018) dan Wulandari (2018) yang menyatakan bahwa variabel audit fee tidak mampu mmemoderasi pengaruh antara audit fee pada auditor switching. Reputasi auditor merupakan nama besar yang dimiliki auditor atas prestasi dan kepercayaan publik yang disandang auditor tersebut. Reputasi auditor sangat menentukan kredibilitas (kualitas dan kepercayaan) suatu laporan keuangan. Bagi para manajemen perusahaan, cenderung menggunakan jasa Kantor Akuntan Publik yang sudah memiliki reputasi yang tinggi, hal itu akan membuat citra suatu perusahaan terangkat dan menambah kepercayaan diri sebuah perusahaan dalam menarik calon investor. Dalam hal ini manajemen beranggapan bahwa Kantor Akuntan Publik besar ataupun Kantor Akuntan Publik kecil sama-sama memiliki reputasi yang baik, sehingga perusahaan tidak perlu melakukan auditor switching. Perbedaan audit fee yang dibayarkan kemungkinan telah sesuai dengan tingkat kompleksitas pekerjaan yang dilakukan oleh KAP dlam melakukan audit atas laporan keuangan. Persetujuan audit fee dalam hal ini sudah dianggap wajar, serta pembayaran audit fee kemungkinan tidak membebani perusahaan. Jadi, berapapun audit fee yang ditawarkan perusahaan oleh Kantor Akuntan Publik besar ataupun Kantor Akuntan Publik kecil selama mereka dapat memberikan opini audit yang sesuai dengan harapan manajemen perusahaan, maka tidak perlu dilakukan auditor switching.

\section{PENUTUP}

Berdasarkan hasil penelitian yang telah didapat melalui pengujian statistik beserta pembahasan seperti yang telah diuraikan diatas pada bab-bab sebelumnya maka dapat disimpulkan bahwa :

Pengaruh independensi terhadap kualitas laporan keuangan terbukti dengan adanya beberapa skandal yang pernah terjadi, fenomena kasus Enron dengan KAP Arthur Anderson yang mana Enron merupakan perusahaan besar yang bergerak dalam industri energi telah melakukan kecurangan dengan memanipulasi data laporan keuangan perusahaan. Untuk menjaga independensi auditor, Pemerintah Indonesia telah mengatur kewajiban rotasi auditor dengan mengeluarkan surat Keputusan Menteri Keuangan Republik Indonesia Nomor 17/PMK.01/2008 tentang "Jasa Akuntan Publik", yang mengatur bahwa pemberian jasa audit umum atau laporan keuangan dari suatu entitas dapat dilakukan paling lama untuk 6 (enam) tahun buku berturut-turut oleh KAP dan 3 (tiga) tahun buku berturut-turut oleh seorang akuntan publik kepada satu klien yang sama (pasal 3 ayat 1 ). Kemudian, KAP dan Akuntan Publik boleh menerima kembali penugasan setelah satu tahun buku tidak memberikan jasa audit umum atas laporan keuangan kepada klien tersebut (pasal 3 ayat 2 dan 3 ).

Financial Distress adalah suatu keadaan yang mana perusahaan sedang mengalami kondisi keuangan yang memburuk. Menurut Hanafi dkk (2000), financial distress yang dihadapi perusahaan dipaparkan diantara dua titik ekstrim, yaitu; kesulitan keuangan jangka pendek (technical insolvency) sampai dengan tingkat yang insolvency (actual insolvency).

Audit Fee menurut Mulyadi (2009:63) merupakan fee yang diterima akuntan publik setelah melaksanakan jasa audit. Seorang auditor bekerja untuk mendapatkan imbalan atau upah yaitu berupa audit fee. Menurut Wijayanti (2010) audit fee dapat definisikan sebagai jumlah biaya (upah) yang diperoleh auditor atas proses audit yang telah mereka lakukan kepada perusahaan kliennya.

Auditor switching merupakan perpindahan auditor atau Kantor Akuntan Publik (KAP) yang dilakukan oleh perusahaan klien (Damayanti dan Sudarma, 2007). Auditor switching dilakukan demi menjaga independensi dan objektivitas yang dimiliki seorang auditor.

Reputasi Auditor Menurut Rudyawan (2008) menyatakan bahwa reputasi auditor merupakan prestasi dan kepercayaan publik yang disandang oleh auditor atas nama besar yang dimiliki auditor tersebut. Klien biasanya mempersepsikan bahwa auditor yang berasal dari Kantor Akuntan Publik besar yang memiliki hubungan dengan Kantor Akuntan Publik internasional akan memiliki kuailitas yang lebih tinggi. 
Penelitian ini menggunakan penelitian kuantitatif dengan pendekatan asosiasif. Variabel yang digunakan dalam penelitian ini adalah finacial distress dan audit fee sebgai variabel indpenden, auditor switching sebagai variabel dependen dan reputasi auditor sebgai variabel moderasi. Populasi yang digunakan dalam penelitian ini adalah perusahaan manufaktur yang terdaftar di Bursa Efek Indonesia tahun 2016-2018. Teknik pengambilan sampel yang digunakan yaitu metode purposive sampling dengan kriteria: 1 ) Perusahaan manufaktur yang terdaftar di Bursa Efek Indoenesia periode 2016-2018; 2) Perusahaan manufaktur yang terdaftar secara berturut-turut di Bursa Efek Indonesia selama periode tahun 2016-2018; 3) Perusahaan tersebut memiliki laporan keuangan tahunan dan laporan audit selama periode tahun 20162018; 4) Perusahaan tersebut melakukan pergantian Kantor Akuntan Publik selama periode tahun 2016-2018. Dari kriteria tersebut diperoleh data untuk sampel sebanyak 37 perusahaan dengan selang periode penelitian selama tiga tahun. Teknik analisis data yang digunakan ialah analisis statistik deskriptif, analisis regresi logistik, dan Moderated Regression Analysis (MRA).

1. Hipotesis 1ditolak yaitu, financial distress tidak berpengaruh pada auditor switching, yang artinya bahwa manajemen beranggapan selama perusahaan masih mampu dalam membayar fee audit, walaupun keadaan perusahaan sedang mengalami financial distress maka perusahaan tidak perlu melakukan auditor switching.

2. Hipotesis 2 ditolak yaitu, audit fee tidak berpengaruh pada auditor switching, yang artinya bahwa manajemen beranggapan KAP yang dipilih sudah sesuai dalam memenuhi kriteria yang dibutuhkan dan dapat sejalan dengan pandangan manajemen yang diinginkan perusahaan, dimana penawaran audit fee yang relatif tinggi bukan merupakan suatu masalah bagi manajemen sehingga perusahaan tidak perlu melakukan auditor switching.

3. Hipotesis 3 ditolak yaitu, reputasi auditor tidak memoderasi pengaruh financial distress pada auditor switching, yang artinya bahwa manajemen beranggapan apapun reputasi auditor yang dipilih oleh perusahaan, mereka akan berpendapat yang sama mengenai financial distress perusahaan sehingga tidak perlu melakukan auditor switching.

4. Hipotesis 4 ditolak yaitu, reputasi auditor tidak memoderasi pengaruh audit fee pada auditor switching, yang artinya bahwa manajemen beranggapan berapapun audit fee yang ditawarkan perusahaan oleh Kantor Akuntan Publik besar ataupun Kantor Akuntan Publik kecil selama mereka dapat memberikan opini audit yang sesuai dengan harapan manajemen perusahaan, maka tidak perlu dilakukan auditor switching.

Berdasarkan hasil analisis dan simpulan diatas, diajukan beberapa saran untuk penelitian yang akan datang dan bagi pihakpihak yang berkepentingan agar mendapatkan hasil yang lebih baik sebagai berikut :

1. Penelitian yang digunakan peneliti hanya terbatas selama tiga tahun saja. Diharapkan untuk penelitian selanjutnya disarankan untuk lebih menggunakan cakupan tahun yang lebih panjang agar dapat memperkuat hasil penelitian sehingga dapat diketahui apakah perusahaan melakukan auditor switching secara mandatory atau perusahaan melakukan auditor switching secara voluntary.

2. Penelitian ini menunjukkan nilai $R$ Square sebesar 0,029, yang artinya variabel bebas yang digunakan pada penelitian ini mempengaruhi variabel terikat sebesar 2,9 $\%$ dan sekitar 97,1 \% dipengaruhi oleh variabel lain di luar penelitian. Diharapkan untuk penelitian selanjutnya agar dapat menyempurnakan penelitian ini dengan menambah beberapa variabel lain yang dapat mempengaruhi auditor switching.

\section{DAFTAR PUSTAKA}

Amalia, Rizki Fitria. 2015, "Pengaruh Opini Audit, Pergantian Manajemen, Audit Fee, terhadap Auditor Switching secara Voluntary dengan Reputasi Auditor Sebagai Variabel Moderating," Jurnal Ekonomi dan Bisnis. Vol 5(3).

American Institute of Certified Public Accountants (AICPA). 1992, Statement of Position: Regarding Mandatory Rotation of Audit Firms of Publicly Held Companies,www.aicpa.org/members/ $\mathrm{div} / \mathrm{secps} / \mathrm{Lit} / \mathrm{sops} / 1900 . \mathrm{htm}$. (diakses pada tanggal 28 maret 2019)

Arinta, Khasaras Dara dan Santosa Adiwibowo. 2013, "Analisis FaktorFaktor yang Mendorong Pergantian Kantor Akuntan Publik," Diponegoro 
Journal Of Accounting. Vol 2(4), P 111.

Ariyani, N.N.t.D., Budiartha, I.K. 2014, "Pengaruh Profitabilitas, Ukuran Perusahaan, Kompleksitas Operasi Perusahaan dan Reputasi KAP terhadap Audit Report Lag pada Perusahaan Manufaktur," E-Jurnal Akuntansi Universitas Udayana. Vol 8(2), P 217-230

Astrini, Novia Retno dan Dul Muid. 2013, "Analisis Faktor-Faktor yang Mempengaruhi Perusahaan Malakukan Auditor Switching Secara Voluntary," Diponegoro Journal of Accounting. Vol 2. P 1-11.

Astuti, Ni Luh Putu Paramita dan I Wayan Ramantha. 2014, "Pengaruh Audit Fee, Opini Going Concern, Financial Distress dan Ukuran Perusahaan pada Pergantian Auditor," E-Jurnal Akuntansi Universitas Udayana. Vol 7(3), P 663-676

Atmini, S. Dan Wuryana. 2005, "Manfaat Laba dan Arus Kas untuk Memprediksi Kondisi Financial Distress pada Perusahaan textile mill product dan appareal and other textile product di BEJ," Simposium Nasional Akuntansi, Vol VII.

Chandegani, Arezoo Aghaei, Zakiah Muhammaddun Mohamed, Azam Jari. 2011, "The Determinant Factors of Auditor Switch among Companies Listed on Tehran Stock Exchange," International Research Journal of Finance and Economics. ISSN 14502887 Issue 80.

Chen Lung, Ching, Gili Yen \& Fu-Hsing Chang. 2009, "Strategic auditor switch and financial distress prediction-empirical findings from the TSE-listed firms," Applied Financial Economics. Vol 19(1), P 59-72.

Craswell, AT. 1998, "The Assosiation between qualified switches," Accounting and Business Research.

Damayanti, S., dan M., Sudarma. 2007, "Faktor-Faktor yang Mempengaruhi Perusahaan Berpindah Kantor
Akuntan Publik," Simposium Nasional Akuntansi XI.

Davis, L.R. Soo, B. And Trompeter, G. 2007, "Auditor Tenure and Ability to Meet or Beat Earning Forecast," Journal of Finance and Economics.

De Angelo, L. E. 1981, "Auditor Size and Audit Quality," Journal of Accounting and Economics. Vol 3(3), P 183-199.

Diaz, Marsela. 2009, Analisis Reaksi Pasar terhadap Pengumuman Pergantian Kantor Akuntan Publik. Skripsi, Politeknik Negeri Pontianak, Kalimantan Barat.

Dong Yu, Michael. 2007, "The Effect of Big Four Office Size on Audit Quality," Journal Faculty of the Graduate School at the University of Missouri:Columbia.

Dwiyanti, R.M.E dan Arifin Sabeni. 2014, "Faktor-Faktor yang Mempengaruhi Auditor Switching secara Voluntary," Diponegoro Journal of Accounting. ISSN: 2337-3806. Vol 3(3).

Faradila, Yuka dan M. Rizal Yahya. 2016, "Pengaruh Opini Audit, Financial distress, dan Perumbuhan Peusahaan Klien Terhadap Auditor Switching (Studi pada Perusahaan Manufaktur yang Terdaftar di Bursa Efek Indonesia Tahun 2010-2014)," Jurnal IImiah Mahasiswa Ekonomi Akuntansi. Vol 1(1), P 81-100.

Firiani, Nurin Ari dan Zulaikha. 2014, "Analisis Faktor-faktor yang Mempengaruhi Voluntary Auditor Switching di Perusahaan Manufaktur Indonesia," Diponegoro Joournal of Accounting. Vol 3(2). P 1-13.

Francis, Jere R. dan Wilson, Earl R. 1988, "Auditor Changes: A Joint Test of Theories Relating to Agrncy Cost and Auditor Differentiation," The Accounting Review. Vol XLIII, P663682.

Ghozali I, 2006. Aplikasi Analisis Multivariate dengan Program SPSS. Semarang Universitas Diponegoro. 
Giri, Ferdinan Efraim. 2010, "Pengaruh Tenur Kantor Akuntan Publik (KAP) dan Reputasi KAP Terhadap Kualitas Audit: Kasus Rotasi Wajib Auditor Di Indonesia," Simposium Nasional Akuntansi 13 Purwokerto.

Gravious, I. 2007, Alternative perspectives to deal with auditors agency problem, Critical Perspektives on Accounting Vol 18, P 451-467.

Halim. 1997, Dasar-dasar Audit Laporan Keuangan. Yogyakarta: Unit penerbit \& percetakan (UPP) AMP YKPN.

Hanafi, Mamduh M, dan Abdul Halim. 2000, Analisis Laporan Keuangan, Yogyakarta: UPP AMP YKPN.

Hanafi, Mamduh M, dan Abdul Halim. 2012, Analisis Laporan Keuangan, Edisi Keempat, Yogyakarta: UPP STIM YKPN.

Handini, Ulfi Yulia Mutiara. 2017, Pengaruh Audit Fee, Opini Going Concern, Financial Distress, Ukuran Perusahaan Klien, Kepemilikan Institusional, dan Kompleksitas Perusahaan Terhadap Auditor Switching. Skripsi, Universitas Muhammadiyah Surakarta.

Hay, D. W. R., Knechel dan H. Ling. 2008, "Evidence on the Impact of Internal Control and Corporate governance on Audit Fees," International Journal of Auditing. Vol 12, P 9-24

Hoitash, R. A., Markelevich, and C. A. Barragato. 2007, "Auditor Fees and Audit Quality," Managerial Auditing Journal. Vol 22 (8), P 761-786.

Hudaib M, dan T.E. Cooke. 2005, "Qualified Audit Opinions And Auditor Switching," Departement of Accounting and Auditee Switch Decision. P 2-5

Ismail, Shahnaz, et. al. 2008, "Why Malaysian Second Board Companies Switch Auditors," Evidence of Bursa Malaysia, International Research Journal of Finance and Economics. Issue 13.
Ismaya, Nur. 2017, Pengaruh Opini Audit, Pergantian Manajemen, Ukuran KAP, Ukuran Perusahaan Klien dan Audit Fee Terhadap Auditor Switching pada Perusahaan Jasa yang Terdaftar Di BEI Tahun 20102015. Skripsi, Institut Agama Islam Negeri Surakarta.

Jensen, M. C., and Meckling W.H. 1976, "Theory of Firm: Managerial Behaviour, Agency Cost and Ownership Structure," Journal of Financial Economics. Vol 3, P 305360.

Keputusan Ketua Umum Institut Akuntan Publik Indonesia Nomor : KEP.024/IAPI/VII/2008 tentang Kebijakan Penentuan Audit fee, Jakarta.

Keputusan Menteri Keuangan Republik Indonesia Nomor 17/KMK.01/2008 tentang Jasa Akuntan Publik, Jakarta.

Keputusan Menteri Keuangan Republik Indonesia Nomor 359/KMK.06/2003 tentang Jasa Akuntan Publik, Jakarta.

Keputusan Menteri Keuangan Republik Indonesia Nomor 423/KMK.06/2002 tentang Jasa Akuntan Publik, Jakarta.

Kurniasari, Desi. 2014, Faktor-Faktor Terkait KAP Switching yang Dilakukan Perusahaan Secara Voluntary, Skripsi, Jurusan Akuntansi Fakultas Ekonomi dan Bisnis Universitas Dian Nuswantoro, Semarang.

Lestari, Hana Puji. 2012, Faktor-Faktor yang Mempengaruhi Perusahaan Manufaktur Terdaftar di BEI Melakukan Voluntary Auditor Switching, Skripsi, Universitas Diponegoro, Semarang.

Mahantara, A.A Gede Widya. 2013, FaktorFaktor yang Mempengaruhi Pergantian Kantor Akuntan Publik pada Perusahaan yang Terdaftar di Bursa Efek Indonesia, Tesis, Jurusan Akuntansi Fakultas Ekonomi dan Bisnis Universitas Udayana, Denpasar. 
Mardiyah, A.A. 2002, Pengaruh Faktor Klien dan Faktor Auditor terhadap Auditor Changes: Sebuah Pendekatan dengan Model Kontijensi RPA (Recursive Model Algorithm). Media Riset Akuntansi, Auditing dan Informasi, Vol 3(2), P 133-154.

Messier, W.F. Glover, S.M, dan Prawitt, D.F. 2005, Auditing and Assurance Services a Systematic Approach, Edisi Keempat, Salemba 4. McGrawHill Irwin. Singapore.

MohammadRezaei, Fakhoddin, dan Norman Mohd-Saleh. 2018, "Audit Firm Ranking, Audit Quality and Audit Fees: Examining Conflicting Price Discrimination Views," International Journal of Accounting.

Muliana Elisa Singgih dan Icuk Rangga Bawono. 2010, "Pengaruh Independensi, Pengalaman, Due Profesional Care dan Akuntabilitas Terhadap Kualitas Audit," Simposium Nasional Akuntansi XIII. P 1-21.

Mulyadi. 2009. Auditing. Edisi 6 Buku 1. Jakarta:Salemba Empat.

Myers, J., L.,A. Myers, dan T. C. Omer. 2003, "Exploring the term of the auditorclient relationship and quality of earnings: A case for mandatory auditor rotation?," The Accounting Review. P 779-799.

Nagy, A. L. 2005, "Mandatory Audit Firm Turnover, Financial Reporting Quality and Client Bergaining Power," Accounting Horizons. Vol 19(2).

Nasser , Wahid, Nazri, dan Hudaib. 2006, "Auditor Client Relationship: The Case of Audit Tenure and Auditor Switching in Malaysia," Managerial Auditing Journal. Vol 21(7), P 724737.

Nasser, A.T.A., Wahid, E.A., Nazri, N.S.F.S.M., Hudaib, M. 2006, "Auditor Client Relationship: The Case of Audit Tenure and Auditor Switching in Malaysia," Managerial Auditing Journal. Vol 21 (7), P 724737.
Nazri, Sharifah et al. 2012, "Factors Influencing Auditor Change: Evidance From Malaysia," Asean Review of Accounting. Vol 20(3), P 22-240.

Nurin Ari Fitriana, Zulaikha. 2014, "Analisis Faktor-Faktor Yang Mempengaruhi Voluntary Auditor Switching Di Perusahaan Manufaktur Indonesia," Diponegoro Journal Of Accounting. Vol 3(2), P1-13.

Peraturan Pemerintah Nomor 20/2015 tentang Praktik Akuntan Publik.

Platt, Harlan d dan Platt, Marjorie B. 2002, "Predicting Corporate Financial Distress: Reflection on choice-Based Sample Bias," Journal.

Prahartari, Frida Aurora. 2013, Analisis Faktor-Faktor yang Mempengaruhi Auditor Switching (Studi Empiris pada Perusahaan Manufaktur yang Terdaftar di Bursa Efek Indonesia), Skripsi, Fakultas Ekonomi dan Bisnis Universitas Islam Negeri Syarif Hidayatullah, Jakarta.

Praptorini, MD dan Januari I. 2007, “Analisis Pengaruh Kualitas Audit, Debt Default dan Opinion Shopping terhadap Penerimaan Opini Going Concern," Naskah Lengkap Simposium Nasional Akuntansi X.

Puspayanti, Ni Putu dan I D G Dharma. (2018), "Pengaruh Financial Distress pada Auditor Switching dengan Reputasi Auditor Sebagai Variabel Moderasi," E-Jurnal Akuntansi Universitas Udayana. Vol 23(2), P 1332-1360.

Putra, Bayu Pratama. 2015, Pengaruh Opini Audit dan Reputasi KAP pada Auditor Switching dengan Financial Distress Sebagai Variabel Moderasi, Skripsi, Universitas Udayana.

Putri Sima, Putu Ayu, dan I Dewa Nyoman Badera. 2018, "Reputasi Auditor Sebagai Pemoderasi Pengaruh Financial Distress dan Audit Fee Pada Auditor Switching," E-jurnal Akuntansi Universitas Udayana. Vol 24(1), P 58-86. 
Rahayu, Santi. 2012, Moderasi Reputasi Auditor Terhadap Faktor-Faktor yang Mempengaruhi Auditor Switching pada Perusahaan Industri Manufaktur yang terdaftar di BEI Tahun 2006-2010, Tesis, Program Pascasarjana Universitas Esa Unggul.

Rahayu, Santi. 2012, Moderasi Reputasi Auditor terhadap Faktor-Faktor yang Mempengaruhi Auditor Switching pada Perusahaan Industri Manufaktur yang Terdaftar di BEI pada Tahun 2006-2010. Tesis, Universitas Esa Unggul, Jakarta.

Rudyawan, Arry Pratama, dan I Dewa Nyoman Badera. 2008, "Opini Audit Going Concern: Kajian Berdasarkan Model Prediksi Kebangkrutan, Pertumbuhan Perusahaan, Leverage, dan Reputasi Auditor," Jurnal Akuntansi. Fakultas Ekonomi, universitas Udayana.

Schwartz, K. B. Dan K. Menon. 1985, "Auditor Switches by Failing Firm," The Accounting Review. Vol 60 (2), P 248-261.

Schwartz, K. B. Dan Soo, B. S. 1995, “An Analysis of Firm 8-K Disclosure of Auditor Changes by Fims Approaching Bankruptcy," Auditing: A Journal of Practice \& Theory. Vol 14(1), P 125-135

Setyorini, T. N. Dan Aloysia Y. A. 2006, "Pengaruh Potensi Kebangkrutan Perusahaan Publik Terhadap Pergantian Auditor," Jurnal kinerja. Vol 10(1), P 76-87.

Sinarwati, Ni Kadek. 2010, “Mengapa Perusahaan Manufaktur yang Terdaftar di BEl Melakukan Pergantian Kantor Akuntan Publik?," Simposium Nasional Akuntansi XIII.

Smith, D.B. dan D.R. Nicholas. 1982, "A Market Reaction Test of Investor Reaction to Client Auditors Disagreement," Diponegoro Journal Of Accounting. Vol 1(2), P 1-12.
Sulistiarini, Endina, dan Sudarno. 2012, "Analisis Faktor-Faktor Pergantian Kantor Akuntan Publik (Studi Empiris Pada Perusahaan Manufaktur di Bursa Efek Indonesia Periode 20062010)," Diponegoro Journal Of Accounting. Vol 1(2), P 1-12

Wibowo, Arie dan Rossieta. Hilda. 2009, "Faktor-Faktor Determinasi Kualitas Audit Suatu Studi dengan Pendekatan Earning Surprise Benchmark," Simposium Nasional Akuntansi XII.

Widyanti, A.A. Sagung, dan I Dewa Nyoman Badera. 2016, "Reputasi Auditor Sebagai Pemoderasi Pengaruh Financial Distress Pada Auditor Switching," E-Jurnal Akuntansi Universitas Udayana. Vol 16(3), P 1800-1828.

Wijayanti, Martina Putri 2010, Analisis Hubungan Auditor-Klien: FaktorFaktor yang Mempengaruhi Auditor Switching di Indonesia, Skripsi, Fakultas Ekonomi dan Bisnis Universitas Diponegoro, Semarang.

Winarna, Jaka. 2005, "Independensi Auditor: Suatu Tantangan di Masa Depan," Jurnal Akuntansi \& Bisnis. Vol 5(2), P 178-186.

Wulan Indah Sari, Ika, dan A.A.G.P Widanaputra. 2016, "Reputasi Auditor Sebagai Pemoderasi Pengaruh Audit Fee Pada Auditor Switching," E-Jurnal Akuntansi Universitas Udayana. Vol 16(1), P 527-556.

Wulandari, M. W dan I Dewa Gede. 2018, "Pengaruh Pergantian Manajemen dan Audit Fee pada Auditor Switching Dengan Reputasi Auditor Sebagai Variabel Moderasi," E-Jurnal Akuntansi Universitas Udayana. Vol 25(1), P 581-605.

Yasmin, Arifia. 2013, Analisis Faktor-Faktor Yang Mempengaruhi Perusahaan Melakukan Pergantian KAP. Skripsi, Universitas Diponegoro, Semarang. 